\section{Visceral leishmaniasis in large Brazilian cities: challenges for control}

\author{
A leishmaniose visceral nos grandes centros \\ urbanos: desafios para o controle
}

\author{
1 Fundação Hemominas, Belo \\ Horizonte, Brasil. \\ 2 Observatório de Saúde \\ Urbana de Belo Horizonte, \\ Universidade Federal de \\ Minas Gerais, Belo Horizonte, \\ Brasil. \\ 3 Secretaria Municipal de \\ Saúde de Belo Horizonte, \\ Belo Horizonte, Brasil. \\ 4 Universidade Federal de \\ Ouro Preto, Ouro Preto, \\ Brasil. \\ Correspondence \\ C. D. L. Oliveira \\ Observatório de Saúde \\ Urbana de Belo Horizonte, \\ Universidade Federal de \\ Minas Gerais. \\ Av. Alfredo Balena 190, \\ Belo Horizonte, $M G$ \\ 30130-100, Brasil. \\ dlorenzo@medicina.ufmg.br
}

\section{Abstract}

The objectives of this article were to discuss the rapid spread of visceral leishmaniasis in urban areas of Brazil and to raise practical questions and perspectives related to control of the disease. Among the proposed methods, the elimination of seropositive dogs is the most controversial and least accepted by society. Its impact on incidence rates varies among studies (positive in some and relatively unimportant in others). Treatment of infected dogs, although widespread in veterinary practice, is based on studies with weak scientific evidence. Insecticide spraying of areas is more acceptable to the population, but is costly and operationally difficult. Intra and inter-urban factors have scarcely been studied and may affect control of the disease. Finally, the article discusses the use of deltamethrin-impregnated dog collars and vaccines, with high expectations for impact on disease transmission, although no product currently available on the market has been fully evaluated, so that further studies are required.

Communicable Disease Control; Visceral Leishmaniasis; Urbanization
Claudia Di Lorenzo Oliveira 1,2

Maria Helena Franco Morais 3

George Luiz Lins Machado-Coelho 4

\section{Introduction}

Visceral leishmaniasis is currently a public health and urban health problem, given its rapid spread in Brazilian metropolitan areas and State capitals in the last 20 years 1,2,3.

In Greater Metropolitan Belo Horizonte, Minas Gerais State, the first confirmed autochthonous case was in 1989, in the municipality of Sabará. In 1994 the first autochthonous case in Belo Horizonte was diagnosed, in the East District of the city, next to the municipality of Sabará 4 . Initially concentrated in the East and Northeast Districts of the city, the disease spread geographically to neighboring areas, with numerous cases occurring in the North and Venda Nova Districts and later in the Northwest and Pampulha Districts, and currently showing an uneven distribution throughout the entire municipality of Belo Horizonte 5. From 1994 to 2005, a total of 757 cases were reported.

Luz et al. 6 identified a rapid spread of the disease in Greater Metropolitan Belo Horizonte and low diagnostic capacity by the municipalities comprising the Metropolitan Area from 1994 to 1999. In 1994 and 1995, human visceral leishmaniasis was reported in (17\%) of the 36 municipalities, increasing to 15 (42\%) in 1998-1999. Recently, despite government efforts, the number of cases reported per year in Greater Metropolitan Belo Horizonte increased significantly (from 162 
cases in 2002 to 262 in 2006) (Francisco Leopoldo Lemos, personal communication; 2008).

The current article focuses on three aspects of visceral leishmaniasis in cities: (i) spread of the disease in urban areas, using Greater Metropolitan Belo Horizonte as an example, (ii) a debate on issues related to control of the disease, and (iii) a discussion of future prospects for control of the disease in the urban context.

\section{Visceral leishmaniasis control}

The geographic spread and urbanization of visceral leishmaniasis led to the need to establish more effective measures for its control. The objectives of the Visceral Leishmaniasis Control Program (PCLV) are to reduce the case-fatality rates and degree of morbidity and to decrease the transmission levels. Strategies include early diagnosis and treatment of human cases, identification and elimination of reservoirs, vector control, and health education. The definition of measures to be developed is supposed to consider the degree of risk in different areas, with the occurrence of human cases as the main indicator. The Program's new focus proposes to incorporate areas without human or canine cases into the surveillance and control measures, thus aiming to avoid or minimize spread of the disease 5 .

In keeping with the Ministry of Health's current proposal for Belo Horizonte, stratification of areas to be covered should be based on the cumulative incidence of human cases, plus information on canine infection and the environmental situation in each area. The areas with the highest human incidence rates coincide with the districts with the highest prevalence of canine infection 8. Based on observations, canine infection also precedes occurrence of the disease in humans 4 . Despite all the measures taken thus far (serological tests in dogs and household vector control in the last five years) the disease has continued to spread, reaching new areas every year.

This expansion can be attributed to several factors, ranging from flaws in control measures to inter and intra-urban differences. Limitations on control measures include difficulties in eliminating the reservoir, insufficient vector control measures (mainly in relation to environmental alterations), and high cost, both financial and social. All these issues mean that the measures primarily focus on the most heavily affected areas, to the detriment of those less affected, which thus becomes a factor allowing geographic spread of the disease. In relation to intra-urban differences, situations related to the socio-environmental context have received little attention in visceral leishmaniasis control. The epidemiological diversity of the various affected districts, the vector's adaptive capacity, and currently unknown factors may be contributing to further spread of the disease.

The importance of dogs in the epidemiological chain of human visceral leishmaniasis has been questioned ${ }^{8}$. In addition to the identification of other reservoirs 9,10, some authors have raised the possibility of humans themselves serving as a reservoir for the disease, principally in relation to leishmaniasis/HIV co-infection 11. However, the impact of these findings on transmission of the disease in the urban context is still unknown.

Meanwhile, dogs have been implicated in all the reported outbreaks, and there is no report in the literature on visceral leishmaniasis epidemics without the presence of infected dogs. Studies have already demonstrated the correlation in spatial distribution between canine and human cases of visceral leishmaniasis and that high canine infection rates increase the odds of transmission to humans in the presence of the vector 12 . Moreira Jr. et al. 13 found no significant association between elimination of dogs and reduction in canine visceral leishmaniasis incidence rates. On the other hand, Ashford 14 and França-Silva et al. 15 demonstrated that the systematic culling of seropositive dogs led to a decrease in human and canine incidence in the areas studied.

According to a case-control study by Borges 16 in Belo Horizonte, dog owners have 2.17 times the odds of having visceral leishmaniasis as compared to non-owners. As for the number of dogs, residents of households with only one dog had 1.87 times the odds of acquiring visceral leishmaniasis, and this risk increased to 3.36 for residents of households with two dogs, as compared to households without dogs.

The possible reasons for failure of dog culling are: lack of continuity, rapid replenishment of the canine population, other visceral leishmaniasis reservoirs, persistence of false-negative dogs due to the low sensitivity of the diagnostic tests, and delay in culling the seropositive dogs 17 .

Culling of seropositive dogs is an increasingly unpopular measure, with low adherence by the community, especially among higher-income dog owners. Dogs are often considered members of the family. This involves a series of social issues that are difficult to approach in the Brazilian context. The leishmaniasis control program views dogs as reservoirs, but sacrificing them can mean a painful family loss, so that owners turn to alternatives like treatment of canine leishmaniasis in order to avoid or postpone euthanasia for their pet. Owners are not concerned about col- 
lective risk, but about their pet's well-being and survival. Changing this individual approach to a more collective vision requires an investment by disease control services in understanding the dog owners' profile. According to current belief, only a small proportion of the population can afford to keep a dog under treatment, which may not actually be true. In addition to the potential risk of selecting strains that are resistant to treatment (which is the same used for human cases), there are still no studies on the impact of this measure on control of the disease or reliable studies on the costs, success, and failure of these treatments in Brazil.

We performed a rapid search for articles in the literature bases and found no clinical trials in Brazil reporting the results of canine treatment. Noli et al. 18 conducted a systematic review of studies on canine treatment and selected 47 clinical trials. Of these, only one was a blind, randomized, placebo-controlled trial, 20 were controlled, non-randomized trials, and 26 were non-controlled. The trials were conducted mainly in Italy, Germany, and France. Despite the incomplete scientific evidence, canine treatment is now well-established clinical practice in veterinary medicine. Given this situation, individual animal and environmental control is imperative, since there is no standardized treatment to date, and thus no supervision or inspection of treatment conditions.

Finally, Camargo-Neves 19 identified culling of infected dogs as the least cost-effective measure for the reduction of human incidence. For all these reasons, dog culling, one of the mainstays of visceral leishmaniasis control, is difficult to implement and has encountered increasing resistance from society.

The other proposed measure for controlling visceral leishmaniasis is vector control. Dog owners accept area chemical spraying better than euthanasia for their pets. However, it is expensive, operationally more complex, and requires more human resources and inputs. Optimization of this measure has been attempted by defining priority areas. Greater effectiveness for this measure requires conducting environmental alterations that hinder the vector's colonization of the area, which depends on behavior changes, a measure for which one expects medium and long-term results.

Finally, it is necessary to evaluate the contextual factors that can directly or indirectly impact control measures. The first point is the fact that municipalities are structured differently and thus have different priorities. Municipalities that already have human cases of visceral leishmaniasis tend to invest more in leishmaniasis control, while those in which the problem is still not visible tend to invest fewer resources.

Added to this fact are inter-urban factors that contribute to making the disease endemic more or less quickly. These factors include the population's age structure, prevalence of malnutrition and HIV infection, numbers of professionals trained to diagnose the disease, laboratory infrastructure for performing tests, and others. These factors interfere directly in the disease's case-fatality rate.

Intra-urban factors include micro-environmental characteristics that may or may not foster the vector's persistence despite the control measures. A study in Greater Metropolitan Belo Horizonte identified the presence of animals in the vicinity and areas with characteristics of a rural-to-urban transition as micro-environmental factors associated with greater occurrence of human cases 20 . França-Silva et al. 15 and Moreno et al. 21 noted that shorthaired dog breeds are more prone to the disease, thus highlighting the importance of assessing the dogs' characteristics in each location. Few such studies have been conducted in our region.

\section{Prospects for control}

This situation leads us to reflect on the feasibility of developing measures to allow blocking the geographic spread and to decrease the number of leishmaniasis cases in large cities that are densely populated and have complex spatial organization, like Belo Horizonte.

New control measures like deltamethrin-impregnated dog collars, although showing promising results in the reduction of human incidence, are costly and difficult to monitor for use as public health control measures. Deltamethrin collars are an important measure for individual prevention, since they act as an effective vector repellant 22 .

The search for an effective vaccine has been one of the key concerns of various research groups. The pioneering work by Genaro et al. 23, evaluating the efficacy of different vaccines produced with raw antigens from $L$. amazonensis, $L$. braziliensis, and L. chagasi as compared to placebo in a canine population in the city of Montes Claros, Minas Gerais State, showed absence of protection, but an important limiting factor in this study was the large number of losses to follow-up.

Palatnik-de-Sousa et al. 24,25 proposed a vaccine based on fucose-mannose ligand (FML) obtained from a strain of $L$. donovani. This vaccine is now being marketed by the Fort Dodge Animal Health laboratory (Overland Park, USA) 
under the trade name Leishmune. Borja-Cabrera et al. ${ }^{26}$ showed in an endemic area in the State of Rio Grande do Norte, Brazil, that this vaccine is immunogenic, with a strong humoral response (97\% seroconversion) and cellular response ( $100 \%$ conversion of the Montenegro skin test). However, thus far there is no way to distinguish between the vaccinal antibodies and those produced by natural infection, and the Brazilian Ministry of Health has demanded euthanasia for all seropositive dogs, regardless of whether they are vaccinated 25 .

New vaccines produced from DNA have been evaluated. Ghosh et al. 27 observed that the DNAA2 vaccine against $L$. donovani increases the cellular and humoral response. Melby et al. 28 and Marques-da-Silva et al. ${ }^{29}$, studying the DNA vaccine LACK (homologue for receptors of activated C kinase), observed a protective effect due to the increased Th1 response. The recombinant antigens TSA, LeIF, and LmSTI1, formulated from two different adjuvants, proved to be excellent inducers of immune response in dogs 30,31.

Despite the various proposals for vaccines produced with different techniques, clinical trials are still needed to prove their efficacy.

\section{Resumo}

O objetivo deste trabalho foi discutir a disseminação da leishmaniose visceral em áreas urbanas considerando a sua rápida expansão, assim como debater questões práticas e perspectivas relacionadas ao controle da doença. Dentre as medidas propostas, a eliminação em massa de cães soropositivos é a mais polêmica e de pior aceitação junto à sociedade. O seu impacto nas taxas de incidência varia entre os estudos avaliados, sendo positivo em alguns e de pouco importância em outros. O tratamento canino, apesar de bastante utilizado na prática veterinária em nosso meio, baseia-se em estudos com fraca evidência científica. A desinsetização das áreas é de melhor aceitação pela população, porém de difícil operacionalização e alto custo. Fatores intra e interurbanos têm sido pouco estudados e podem interferir no controle da doença. Por fim, discute-se o uso da coleira impregnada e da vacina, cuja expectativa quanto ao impacto na transmissão da doença é grande, embora nenhum produto disponível no mercado esteja devidamente avaliado, demandando ainda maiores estudos.

Controle de Doenças Transmissíveis; Leishmaniose Visceral; Urbanização

\section{Conclusions}

Visceral leishmaniasis, although an old public health problem, still poses basic unresolved issues. The current control program is based on measures whose effectiveness is questioned and whose cost-effectiveness has scarcely been analyzed. Meanwhile, the research does not point to safe and economically viable alternatives. Health professionals working in visceral leishmaniasis control are constantly pressured by dog owners and the mass media to present a solution to the disease's spread and increasing incidence rates. It is up to funding agencies to provide the resources for conducting research capable of producing viable control alternatives and practical responses within a reasonable timeframe and at a feasible cost in order to move beyond the currently established measures.

\section{Contributors}

All of the authors participated equally in elaborating the manuscript. More specifically, C. D. L. Oliveira coordinated the group and was responsible for the review on canine leishmaniasis treatment and urbanization of the disease, M. H. F. Morais was in charge of the discussion on control of the disease in Belo Horizonte, and G. L. L. Machado-Coelho was responsible for the review on vaccine trials. 


\section{References}

1. Jeronimo SM, Oliveira RM, Mackay S, Costa RM, Sweet J, Nascimento ET, et. al. An urban outbreak of visceral leishmaniasis in Natal, Brazil. Trans R Soc Trop Med Hyg 1994; 88:386-8.

2. Cunha S, Freire M, Eulalio C, Critosvao J, Netto E, Johnson Jr. WD, et al. Visceral leishmaniasis in a new ecological niche near a major metropolitan area of Brazil. Trans R Soc Trop Med Hyg 1995; 89:155-8.

3. Genaro O, Costa CA, Williams P, Silva JE, Rocha NM, Lima SL, et. al. Ocorrência de calazar em área urbana da grande Belo Horizonte, MG. Rev Soc Bras Med Trop 1990; 23:121.

4. Oliveira CL, Assunção RM, Reis IA, Proietti FA. Spatial distribution of human and canine visceral leishmaniasis in Belo Horizonte, Minas Gerais State, Brazil, 1994-1997. Cad Saúde Pública 2001; 17:1231-9.

5. Perfil epidemiológico e medidas de prevenção e controle da leishmaniose visceral. Boletim Epidemiológico da Secretaria Municipal de Saúde de Belo Horizonte 2006; 1:6-11.

6. Luz ZMP, Pimenta DN, Cabral ALLV, Fiúza VOP, Rabelo AM. A urbanização das leishmanioses e a baixa resolutividade diagnóstica em municípios da Região Metropolitana de Belo Horizonte. Rev Soc Bras Med Trop 2001; 34:249-54.

7. Departamento de Vigilância Epidemiológica, Secretaria de Vigilância em Saúde, Ministério da Saúde. Manual de vigilância e controle da leishmaniose visceral. Série A: normas e manuais técnicos. Brasília: Ministério da Saúde; 2004.

8. Dietze R, Barros GB, Teixeira L, Harris J, Michelson $\mathrm{K}$, Falqueto A, et al. Effect of eliminating seropositive canines on the transmission of visceral leishmaniasis in Brazil. Clin Infect Dis 1997; 25:1240-2.

9. Sherlock IA. Ecological interactions of visceral leishmaniasis in the state of Bahia, Brazil. Mem Inst Oswaldo Cruz 1996; 91:671-83.

10. Savani ES, Oliveira-Camargo MC, Carvalho MR, Zampieri RA, Santos MG, D'Auria SR, et al. The first record in the Americas of an autochthonous case of Leishmania (Leishmania) infantum chagasi in a domestic cat (Felix catus) from Cotia County, São Paulo State, Brazil. Vet Parasitol 2004; 120:229-33.

11. Molina R, Lohse JM, Pulido F, Laguna F, LópezVélez R, Alvar J. Infection of sand flies by humans coinfected with Leishmania infantum and human immunodeficiency virus. Am J Trop Med Hyg 1999; 60:51-3.

12. Camargo-Neves VL, Katz FG, Rodas LAC, Poletto DW, Lage LC, Spinola RMF, et al. Utilização de ferramentas de análise espacial na vigilância epidemiológica de leishmaniose visceral americana - Araçatuba, São Paulo, Brasil, 1998-1999. Cad Saúde Pública 2001; 15:1263-7.

13. Moreira Jr. ED, Souza VMM, Sreenivasan M, Nascimento EG, Carvalho LP. Assessment of optimized dog-culling program in the dynamics of canine Leishmania transmission. Vet Parasitol 2004; 122:245-52.
14. Ashorf RW. Leishmaniasis reservoirs and their significance in control. Clin Dermatol 1996; 14: 523-32.

15. França-Silva JC, Costa RT, Siqueira AM, MachadoCoelho GLL, Costa CA, Mayrink W, et al. Epidemiology of canine visceral leishmaniasis in endemic area of Montes Claros Municipality, Minas Gerais. Vet Parasitol 2003; 111:161-73.

16. Borges BKA. Fatores de risco para leishmaniose visceral em Belo Horizonte, 2006 [Masters Thesis]. Belo Horizonte: Escola de Veterinária, Universidade Federal de Minas Gerais; 2006.

17. Dantas-Torres F, Brandão-Filho SP. Leishmaniose visceral no Brasil: revisitando os paradigmas da epidemiologia e controle. Rev Inst Med Trop São Paulo 2006; 48:151-6.

18. Noli C, Auxilia ST. Treatment of canine Old World visceral leishmaniasis: a systematic review. Vet Dermatol 2005; 16:213-32.

19. Camargo-Neves VLF. Aspectos epidemiológicos e avaliação das medidas de controle da leishmaniose visceral americana no Estado de São Paulo, Brasil, 2004 [Doctoral Dissertation]. São Paulo: Faculdade de Saúde Pública, Universidade de São Paulo; 2004.

20. Oliveira CL, Diez-Roux A, César CC, Proietti FA. A case-control study of microenvironmental risk factors for urban visceral leishmaniasis in a large city of Brazil, 1999-2000. Rev Panam Salud Pública 2006; 20:369-76.

21. Moreno EC, Melo MN, Genaro O, Lambertucci JR, Serufo JC, Andrade AJ, et al. Risk factors for Leishmania chagasi infection in an urban area of Minas Gerais State. Rev Soc Bras Med Trop 2005; 38: 456-63.

22. David JR, Stamm LM, Bezerra HS, Souza RN, Killick-Kendrick R, Lima JW. Deltamethrin-impregnated dog collars have a potent anti-feeding and insecticidal effect on Lutzomyia longipalpis and Lutzomyia migonei. Mem Inst Oswaldo Cruz 2001; 96:839-47.

23. Genaro O, Pinto JA, Costa CA, França-Silva JC, Silva JC, Sanguinetti LSR, et al. Phase III randomized double-blind clinical trial of efficacy of a vaccine against canine visceral leishmaniasis in urban area of Montes Claros, MG, Brazil. Mem Inst Oswaldo Cruz 1996; 91:166.

24. Palatinik-de-Sousa CB, Dutra HS, Borojevic R. Leishmania donovani surface glycoconjugate GP36 is the major immunogen component of the fucose mannose ligand (FML). Acta Trop 1993; 53:59-72.

25. Palatnik-de-Sousa CB, Gomes EM, Souza EP, Santos WR, Macedo SR, Medeiros LV, et al. The FML (Fucose Mannose Ligand) of Leishmania donovani: a new tool in diagnosis, prognosis, transfusional control and vaccination against human kala-azar. Rev Soc Bras Med Trop 1996; 29:153-63.

26. Borja-Cabrera GP, Correia-Pontes NN, Silva VO, Paraguai-de-Souza E, Santos WR, Gomes EM, et al. Long-lasting protection against canine kala-azar using the FML-Quil A saponin vaccine in an endemic area of Brazil (São Gonçalo do Amarante, RN). Vaccine 2002; 20:3277-84. 
27. Ghosh A, Zhang WW, Matlashewski G. Immunization with A2 protein results in a mixed Th1/Th2 and a humoral response which protects mice against Leishmania donovani infections. Vaccine 2001; 20:59-66.

28. Melby PC, Chandrasekar B, Zhao W, Coe JE. The hamster as a model of human visceral leishmaniasis: progressive disease and impaired generation of nitric oxide in the face of a prominent Th1-like cytokine response. J Immunol 2001; 166:1912-20.

29. Marques-da-Silva EA, Coelho EA, Gomes DC, Vilela MC, Masioli CZ, Tavares CA, et al. Intramuscular immunization with p36(LACK) DNA vaccine induces IFN-gamma production but does not protect BALB/c mice against Leishmania chagasi intravenous challenge. Parasitol Res 2005; 98:67-74.
30. Skeiky YA, Coler RN, Brannon M, Stromberg E, Greeson K, Crane RT, et al. Protective efficacy of a tandemly linked, multi-subunit recombinant leishmanial vaccine (Leish-111f) formulated in MPL adjuvant. Vaccine 2002; 20:3292-303.

31. Fujiwara RT, Vale AM, França-da-Silva JC, Costa RT, Quetz JS, Martins Filho OA, et al. Immunogenicity in dogs of three recombinant antigens (TSA, LeIF and LmSTI1) potential vaccine candidates for canine visceral leishmaniasis. Vet Res 2005; 36: 827-38.

Submitted on $06 / \mathrm{Mar} / 2008$

Approved on 10/Mar/2008 